\title{
EFL teachers' beliefs and practices about digital learning of English
}

\author{
1Arif Nugroho*, 2Ira Mutiaraningrum \\ ${ }^{1}$ IAIN Surakarta, Central Java, Indonesia \\ ${ }^{2}$ State Polytechnic of Sambas, West Kalimantan, Indonesia \\ *Corresponding Author \\ Email: arifnugroho.iainsurakarta@gmail.com
}

\begin{abstract}
The last two decades have been the witness of many studies reporting the disparity between EFL teachers' beliefs and practices in technology integration around the world. Notwithstanding the enormous studies on EFL teachers' beliefs and perceptions of digital technology use for language classroom, the literature has still been silent on the relation between Indonesian EFL teachers' beliefs and practices. The present study thus sheds some light on 15 EFL teachers' beliefs and practices about digital learning of English in Indonesia. Drawing on data from the written reflections and semi-structured interviews, the findings revealed that these EFL teachers were well equipped with the importance and objective of teaching English by means of digital devices, but appeared hesitant and lacked of preparation in their teaching practices. The semi-structured interview further depicted that their unconfident and lack of preparation was not only a result of inadequate training but also of limited resources and digital facilitation. The institutional supports influenced by environmental readiness also affected their efficacy for digital learning of English. The findings contribute to the realm of English language teaching with regards to offering literature of EFL teachers' professional development.
\end{abstract}

Keywords: teachers' beliefs; teachers' practices; digital learning of English; teacher professional development

$\begin{array}{llll}\text { Received: } & \text { Revised: } & \text { Accepted: } & \text { Published: } \\ \text { 10 April 2020 } & \text { 25 August 2020 } & \text { 27 August 2020 } & 31 \text { August 2020 }\end{array}$

\section{INTRODUCTION}

In recent years, EFL teacher cognition has been studied as an independent research variable, with a primary concern on what teachers think, believe, and recognize about their teaching activities (Borg, 2015). Even though the previous literature has explored how EFL teachers involve in the use of digital technology, e.g. social networking sites for language learning, the disparity between their beliefs and practices about digital learning still remains a mystery, especially in Indonesian EFL context. Hitherto, technology is a crucial part of human life, and used as efforts to enhance the efficacy of language learning and activities (Voogt et al., 2009; Voogt \& McKenney, 2017). 
Nugroho, A., \& Mutiaraningrum, I. (2020). EFL teachers' beliefs and practices about digital learning of English. EduLite: Journal of English Education, Literature, and Culture, 5 (2), 304-321. DOI: http://dx.doi.org/10.30659/e.5.2.304-321

With its importance for language learning, pedagogical knowledge of technology integration in language classroom is a competency that educators in the twenty-first century must have and should be enormously spotlighted in teacher training programs and professional development (Lestariningsih et al., 2020; Galvis, 2012). However, some previous researches reported that EFL teachers have not been equipped well with sufficient support of digital learning skills, such as using computer tools or software program (Celik, 2013; Nordin et al., 2013).

With rapid affordances of technology, EFL professionals have recently begun to pay attention on how EFL teachers and students learn and practice English by using a variety of digital devices and technology resources (Sundqvist \& Sylvén, 2016). With their concern on learners' autonomy, Lee and Drajati (2019) define this phenomenon as digital learning of English, which is explained as EFL learner activities by employing a range of digital devices, e.g. computer, tablet, web apps, and smartphones. With this era, EFL teacher thoughts, beliefs, and practices of using digital devices are a central object as a means to systematically develop an effective use of technology for language learning. To date, studies on this area show that teachers' beliefs often did not align with their classroom technology practices (Ertmer et al., 2012; Kim et al., 2013). That is, EFL teachers tended to use technology in fairly traditional ways, i.e. asking learners to complete drills or filling computer-based worksheets (Ottenbreit-Leftwich et al., 2018). Reasons for the gap occurred between the teachers' beliefs and teaching administration seemed to relate to external constrains such as the limited access of internet resources, pre-determined curricular, or professional trainings (Liu et al., 2017).

As an effort to understand the disparity between EFL teacher beliefs and practices, two set of barriers are often discussed (Ertmer et al., 2012). The first-order barriers focus on environmental readiness factors such as computer access, internet resources, and knowledge of teachers. The secondorder barriers further concern on some factors, i.e. teachers' cognition, belief, and thought. The second-order barriers, also called as the intrinsic factors, can interfere teacher performance in integrating technology for language classroom even when the first-order barriers have been overcome (Hew \& Brush, 2007). It is widely accepted that digital technology availability creates effective technology-based learning, but the acquisition of teachers' pedagogy and skills are highly required to accomplish the full potential of technology integration in language classroom (Koehler et al., 2013; Rahamat, 2019). Nonetheless, the mastery of digital technology concept and knowledge does not merely guarantee the effectiveness of technology integration (Tondeur et al., 2017). Teachers' persistent thoughts and beliefs about particular teaching practices are often identified as the second-order barriers that impede the efficacy of technology integration in a language classroom (Ertmer \& Ottenbreit-Leftwich, 2010). Teachers' beliefs forecast, reflect, and ensure their real teaching practices (Wilkins, 2008). This implies that how teachers teach can be different even when they hold similar knowledge and skills, depending on their beliefs. Teachers' beliefs are recognized even more dominant than their knowledge and pedagogy (Kim et al., 2013). Hence, understanding 
teachers' beliefs of digital technology use for language learning would be fruitful in improving the quality of technology integration practices.

Provided with the fact that classroom context are constantly shifting to digital era, it is highly necessary that the second-order barriers to digital technology learning should be overcome. It is recognized that positive changes in teachers' beliefs could close the disparity and help surmount the secondorder barriers (Ertmer et al., 2012). In view of the significance of technology integration, the present study seeks to investigate EFL teachers' beliefs and practices about digital learning of English in Indonesian EFL context. Drawing on self-reported data from a group of university EFL teachers, the results of this study will not only contribute to the existing literature of EFL teachers' cognitions in technology-based teaching, but it will also draw on the gap between EFL teachers' beliefs and teaching practices and shed some light on the institutional and professional development factors. This study can further initiate valuable implications for pre- and in-service EFL teacher professional development programs on how to equip EFL teachers with pedagogic competence and knowledge in teaching English by means of digital technologies. The present study is guided by the research questions: (1) what specific beliefs do Indonesian EFL teachers hold about digital learning of English? and (2) how are their beliefs implemented in their teaching practices?

Borg (2015) defines teachers' cognition as what they know, think, and believe. Notwithstanding the fact that the development of EFL teachers' beliefs can greatly influence their teaching performances, a potential disparity between the teachers' beliefs and practices can still exist (Borg, 2015; Yuan \& Lee, 2014). In many EFL context, EFL teachers' are frequently challenged by a variety of constraints, i.e. limited resources, a stiff school curriculum, and institutional support (Zheng \& Borg, 2014). These limitations lead to the disparity between EFL teachers' beliefs and practices, particularly in teaching English by integrating digital technology.

Previous literature indicated that teachers' beliefs, especially in the area of classroom technology integration, often did not associate to their teaching practices (Ertmer et al., 2012). Perhaps one of the most famous studies in this area was the one conducted by Lam (2000). This was regarded as an initial study examining teachers' beliefs and presented a contrariety between the institutions needs to integrate technology in the classroom that was referred as technophilia, and a fierce rejection from the teachers to utilize technology, which was referred as technophobia (Lam, 2000). Through his results, Lam (2000) believed that institutions could suffer from technophilia, however a particular attention as resulted in this study was that some factors closely related to the lack of technology use could allegedly be the teachers' ages and experiences. The results of Lam's study, in fact, revealed that teachers at the age between 25 and 35 were actively using technology, whereas the teachers at the age of 35 and up were not reporting any technology use. Some years later, a study of Yang and Huang (2008) aimed at investigating Taiwanese EFL teachers' attitudes and behaviours in using technology for language classroom seemed to refute the results of Lam (2000). Yang and Huang's (2008) results suggested that senior teachers struggled more to use digital technology in the 
Nugroho, A., \& Mutiaraningrum, I. (2020). EFL teachers' beliefs and practices about digital learning of English. EduLite: Journal of English Education, Literature, and Culture, 5 (2), 304-321. DOI: http://dx.doi.org/10.30659/e.5.2.304-321

classroom than did the 'experienced' teachers. Although the result contradicts Lam's (2000), on the other way, the results of Yang and Hung (2008) simultaneously reinforce the significance of technology integration in language classroom. Since then, examining the discrepancy between teachers' beliefs and teaching practices becomes an interesting research area that attracts attention from EFL professionals.

More recently, Kim et al. (2013) employed an exploratory mixed methods to understand how the beliefs of teachers were correlated to technology-based classroom practices. The results indicated that although all participating EFL teachers have experienced the same portion of technological knowledge, professional workshops, and pedagogical skills, the practices and levels of the teachers in integrating technology in the language classroom were not the same. The reason for this phenomenon, as depicted in Kim's et al. (2013) study, was that the teachers' technology integration was strongly influenced by their beliefs and motives. These results imply that if appropriate supports are given to EFL teachers in line with their beliefs, their efficacy of technology integration practices can be improved. A study examining Saudi Arabian EFL teachers' perceptions on computer applications conducted by Mohsen and Shafeeq (2014) further confirmed the results of Kim et al. (2013). Mohsen and Shafeeq (2014) revealed that the EFL teachers' use of technology for English classroom as a blended learning was still limited in terms of administrative issues, instead of pedagogical significance for language learning. In a similar direction, the findings of Lan and Lam (2020), on their study examining a Chinese EFL teacher' belief and practice, indicated that in general, the teacher implemented her beliefs in the language classroom. Although some disparities existed, the reasons were determined by some teaching contextual factors, such as the lack of teaching preparation and the level of language proficiency. The results of Lan and Lam (2020) further suggested that it is strongly suggested for EFL teachers to systematically and regularly scrutinize the correlation between their beliefs and teaching practices for a better quality of their teaching application, particularly in digital learning of English.

Given the contextual disparities between teachers' beliefs and classroom practices as shown by the above review of literature, the question arises is that "how do Indonesian EFL teachers' beliefs relate to their teaching practices with technology integration?" Thus far, in Indonesian EFL context, a lot of studies in terms of EFL teachers' cognition have greatly emphasized on the teachers' beliefs and perceptions about digital technology for language learning (e.g. Inayati \& Emaliana, 2017; Al-Munawwarah, 2015). The literature has still been silent on the relation between Indonesian EFL teachers' beliefs and how they carry out their beliefs into actual teaching practices. To fill the gap, the present inquiry aims to explore Indonesian EFL teachers' beliefs about digital learning of English and how the teachers enact their beliefs into their teaching practices. Written reflections and semi-structured interviews are used to elicit the data from 15 EFL university teachers teaching English as a foreign language in an Indonesian university. 


\section{METHOD}

\section{Context and participants}

The present study is based in a public university in Central Java Indonesia, where English is treated as a foreign language. The university consists of several faculties including faculty of language and culture where English department belongs to. In addition, the university has a center for language department conducting English language for specific program. Hence, the participants of this study were lecturers teaching at the English department and the center for language development. The data were gathered in the age of covid-19 pandemic in March to April 2020 where inside classroom learning shifted to outside classroom or online learning by means of digital devices in social distancing measures. However, the researchers ensured that the participants already experienced digital learning of English since they have been teaching for at least three years. The participants were 15 non-native EFL university teachers (10 female, 5 male) who were purposively selected based on two primary criteria, (1) integrating digital tools such as smartphones, computer devices, and web-applications in their teaching of English and (2) having experience of teaching English at least for three years. The participants' age varied between 28 and 43, with the average age was 33 . All the EFL teachers had a master degree $(n=13)$ and doctoral candidate $(n=2)$ in English language teaching and linguistics studies. Their native language is Indonesian and their teaching experience ranges from 3 to 15 years.

\section{Research model and instruments}

A case study design was chosen in this study to explore EFL teachers' beliefs and their classroom practices of digital learning in English language teaching. The case study model is based on Yin (2015), that aims to scrutinize an upclose, in-depth, and detailed delineation of the teachers' beliefs and practices in using technology in their classroom. To meet the objective, this study employed written reflections and semi-structured interviews as instruments for data collection. First, written reflection is a written story template comprising a set of questions or/and instructions and blank spaces where participants write their responses (Barkhuizen, 2014). The primary benefit of this inquiry tool is for participants to produce an intelligible answer or responses by filling in the spaces based on their own reflections or experiences (Onwuegbuzie et al., 2010). In a case study context, using written reflections, which is a nonverbal communication, is somehow meaningful for obtaining a deeper shared information and meaning (Hollweck, 2015). Second, semistructured interview is a method of inquiry which is open, enabling new ideas and questions to be raised during the conversation as a result of what the interviewee says (Harding, 2018). One of benefits is that the researchers, as interviewer, possess structured guidance in hand, but still possible to extend the guidance when a new issue come up during the dialogue (Nugroho et al., 2020). For these reasons, written reflections and semi-structured interviews were kindly selected as research instruments for this study.

\section{Data collection and analysis}

The current study aims to shed some light on EFL teachers' beliefs and classroom practices about digital learning of English in Indonesia. To this end, 
Nugroho, A., \& Mutiaraningrum, I. (2020). EFL teachers' beliefs and practices about digital learning of English. EduLite: Journal of English Education, Literature, and Culture, 5 (2), 304-321. DOI: http://dx.doi.org/10.30659/e.5.2.304-321

the 15 participants (named $\mathrm{P} 1-\mathrm{P} 15)$ were required to write self-reflections by answering list of questions (see appendix) with regards to perception and practices of using digital learning of English to conduct teaching activities. 6 of the 15 participants (i.e. $\mathrm{P} 1, \mathrm{P} 3, \mathrm{P} 6, \mathrm{P}_{11}, \mathrm{P}_{14}$, and $\mathrm{P} 15$ ) were invited for semistructured interview to follow up their fascinating experiences and stories written in their reflections, thus the researchers considered that they were worthy of more in-depth investigation. The semi-structured interviews were conducted individually and last about 30 minutes each by using call phone. Not only did they were asked to come up with detailed examples to delineate their beliefs about digital learning of English, but they were also required to explore some factors for the gap between their existing beliefs and their teaching practices as well as to reveal the viable reasons behind these. The semi-structured interviews were recorded by taking some notes as well as by means of audio recording and transcribed for the sake of data analysis. Ethical approval and consent were sought from the participants before conducting data collection.

Referencing to the research questions and existing literature (Galvis, 2012; Lailiyah \& Cahyono, 2017; Liu et al., 2017), the researchers attentively reviewed the data both from written reflections and semi-structured interview. The researchers further analysed and identified important themes and codes that reflect the participants' beliefs about digital learning of English. The participants' responses were classified into some themes, the importance of digital technology in English language learning, how the participants integrate digital technology in language classroom, etc. Moreover, to ease the data classification, coding was conducted based on the emerging themes and differentiate the participants' responses either from written reflections (WR) or interviews (Int) combined with the name of the participants, i.e. P2 WR, P11 Int. The researchers also did a comparison between the EFL teachers' beliefs and their teaching practices to recognize the congruence and disparity between their perception and actual teaching practices. Thereafter, the authors analysed, reviewed, and integrated the emerging themes as reflected from the 15 participants that further led to the final results of data analysis and conclusion drawing. As an effort to maintain the validity and reliability of this study, the two researchers coded the data from both written reflections and interviews independently, continued by stages of discussion to achieve the consensus on the final results. 


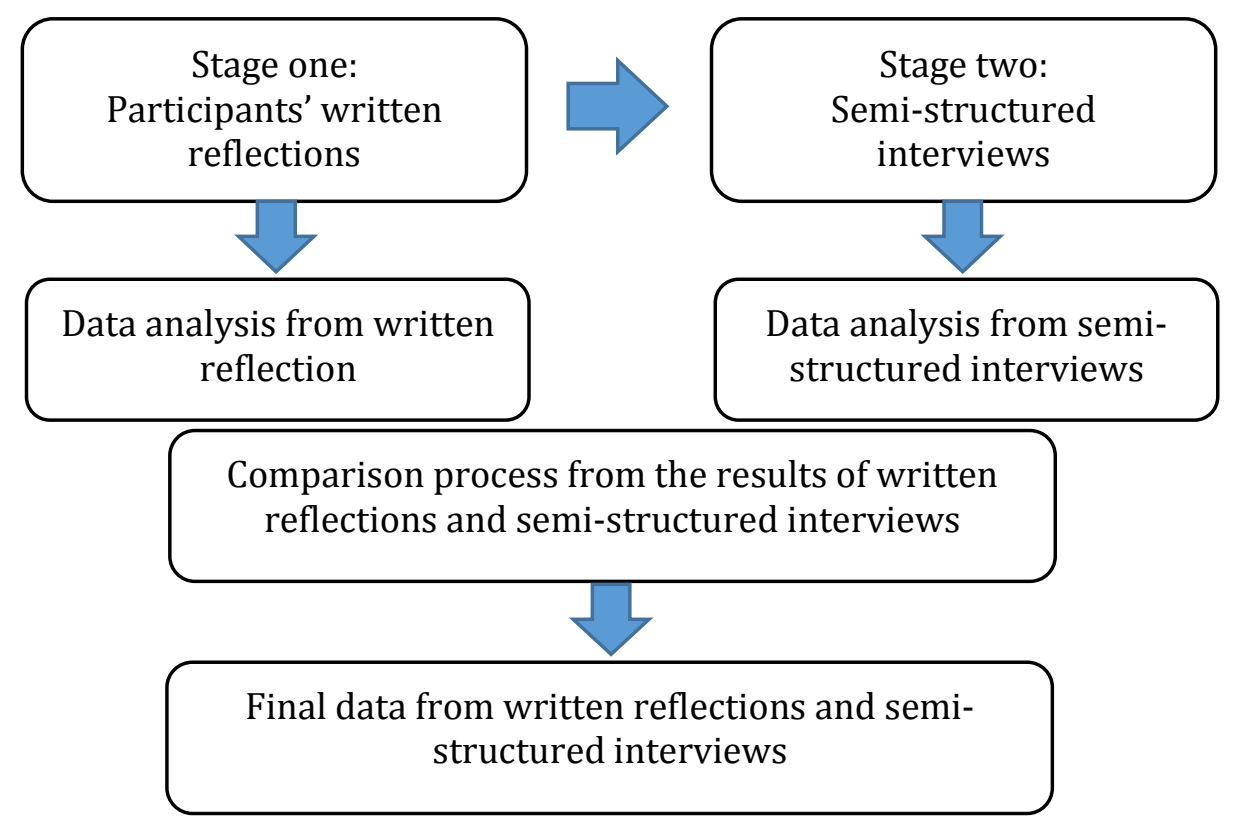

Figure 1. Procedure of data collection and analysis

\section{RESULTS AND DISCUSSION}

This section highlights the main two themes with regard to EFL teachers' beliefs about digital learning of English, and whether and how they implement their beliefs in their classroom practices. The most representative quotes from the participants' responses both in written reflections and semi-structured interview are written to support the delineation of the findings. The quotes from written reflections are coded as "WR", while the semi-structured interviews are signed as "Int". The interpretation of the results and how they relate to current theories and previous studies are further presented as a discussion.

\section{The importance of technology integration in language learning}

In general, all EFL teachers realize the importance of integrating technology and digital learning in the classroom in the age of twenty-first century teaching. As stated by the participants in their written reflections, digital technologies and mobile devices if used properly, can increase EFL learners' self confidence and motivation, facilitate them to do more practices, trigger their learning autonomy, and have significant impacts on other parts of language learning. For instance, $\mathrm{P} 12$ shared how digital learning of English can contribute to learners' language development.

Nowadays, the use of technology in EFL learning is a demand. If used in appropriate manner, it will benefit EFL learners to improve their English skills by doing more practices through available social media in daily life. Besides, digital learning can increase learners' confidence and foster their learning autonomy. (P12. WR) 
Nugroho, A., \& Mutiaraningrum, I. (2020). EFL teachers' beliefs and practices about digital learning of English. EduLite: Journal of English Education, Literature, and Culture, 5 (2), 304-321. DOI: http://dx.doi.org/10.30659/e.5.2.304-321

Some EFL teachers also believed that learners could enjoy teaching activities by means of digital technology, which can highly contribute to their learning interest and willingness to communicate through online platform.

By using digital devices, e.g. WhatsApp or Google classroom, learners are highly motivated and willing to involve in the teaching activities and discussion, that in the face-to-face meeting they tend to be shy and silent. Through online platform, they are asking questions, answering teachers' questions, and responding to their friends' opinions, and expressing their idea. (P15. Int)

I was inspired to use social media Instagram as a medium to enhance learners' writing skills, and I found they were giving online peer feedback in an interesting way through Instagram comments, both from teacher and other students. (P1. Int)

P7 also pointed out that digital learning of English should be included in daily classroom teaching to assist EFL learners improve their productive skills, i.e. speaking and writing.

Above all, digital learning should be part of nowadays English curriculum and should be part of learners' daily activities of learning in order to develop their productive skills of speaking and writing, thus they will be able to competitively bargain in the work-places. (P7. WR)

\section{Social networking sites in English language learning}

EFL teachers' beliefs in the value of using digital technology in language learning closely relates to the fact that English is treated as a foreign language in Indonesia. Without adequate language exposure and opportunities in their daily life, EFL learners' productive skills are likely to fall into a state of disuse. The indivisible use of smartphone in learners' daily life today should be a great chance to provide the language exposure. Hence, integrating digital devices that are accessible from learners' smartphone to practicing English is a worth trying to foster their language development.

As most of my students are native Indonesian, they are often reluctant in performing speaking in English. A lot of and continuous practices are highly needed to improve their fluency. One of ways is using technology in their daily life. It could be done through video blog, short video in Instagram, voice note recording, etc. (P8. WR)

Likewise, several participants also believed that teaching English through digital technologies has a potential of developing fluency and build confidence among EFL learners to have communication in English. Moreover, some others strongly thought that digital learning activities brought a positive effect on their students' enjoyment which was identified as a crucial factor for learners' motivation, engagement, and performance.

As far as I concern, since I integrate technology such as Instagram and quizzes in the Kahoot in my classroom, in spite of some limitation, my students tend to confidently speak and communicate in English. Once a month in average since I teach speaking at this university, I assign my students to create a short video blog and post it in Instagram. It seems improve their confidence and fluency. (P11. Int) 
With regard to my experience, using technology in English classroom has a positive influence to learners' enjoyment, and this will increase their motivation and active engagement in learning activities. (P6. Int)

Typically, most participants relied on technology innovations and the integration of social networking sites in language classroom offer EFL learners greater affordances for authentic language use and sociocultural knowledge than are available inside the classroom. They believed that hitherto, social media networks are becoming part of learners' daily life and are inseparable from them. A participant added that EFL teachers must see this phenomenon as an opportunity to incorporate language practices in EFL learners' daily activities.

To develop learners' critical thinking and communicative competence, we have to equip them with as many as authentic language use and cross-cultural knowledge. This will be more effective when EFL learners are given a daily exposure to authentic materials, and the most effective way is through social media networks. (P9. WR)

To the best of my knowledge, I strongly believe that integrating English practices in EFL learners' daily life can massively improve their English skills. EFL teachers must recognize this as challenge as well as opportunity. (P14. Int)

In a nutshell, the participants emphasized their beliefs of the importance to explicitly integrate digital technologies in language classroom to assist the learners overcome possible stagnation in their English practices and develop their communicative competence.

\section{EFL teachers' challenges of using technology in language learning}

Although the participants recognized the importance of using digital technology in their language classroom, most of them encountered challenges to carry out their beliefs in classroom practices because of a range of personal and contextual constrains. The disparity between their beliefs and classroom practices hence resulted in a lack of efficacy in teaching English by means of digital devices.

I found it difficult to teach my classroom using technology because I have to do so many preparations before the class. This takes my time a lot so as consume my energy. However, it must be tried to improve the learning efficacy. (P4. WR)

The reasons behind their lack of readiness are complicated. First, as nonnative speakers of English, some participants felt a sense of hesitant when they have to give an example of performing correct English by using digital devices (e.g. speaking using Instagram). They shared their uncertainty if they can be a good example since by using digital technology, all recorded activity are automatically archived.

I never thought that I could be a good example especially for speaking English for my students. Thus, if we use technology, it will widely be spread and somehow I am not confident with my English. (P14. Int)

Even when some participants tried to use digital technologies in their classroom, they have to deal with a limited time due to a rigid English 
Nugroho, A., \& Mutiaraningrum, I. (2020). EFL teachers' beliefs and practices about digital learning of English. EduLite: Journal of English Education, Literature, and Culture, 5 (2), 304-321. DOI: http://dx.doi.org/10.30659/e.5.2.304-321

curriculum that was still focused on grammar accuracy. As a result, a face-toface meeting and teacher-centred method were mostly preferred. In addition, when they integrated digital technology in their teaching practices, they often encountered some sources limitations, such as poor internet connection and compatibility issues both for teachers' and students' devices.

We sometimes have a limited time to use digital technology I our classroom. We often run for grammar materials that should be completed within the semester thus a conventional teaching where the teacher is the source of knowledge is usually preferred. (P2. WR)

In addition, when we have prepared teaching activities by using technology, we often encounter some technical problems in the classroom at the time we start the class, such as poor internet connection and the compatibility of particular devices. (P3. Int)

Furthermore, the participants' lack of efficacy highly correlated with their inadequate professional skills in teaching English by using digital technology due to insufficient knowledge and training during their pre-service program. Also, they seemed to have limited opportunities and awareness to develop their pedagogical skills through professional development in the university. For instance, notwithstanding the fact that they believed that the digital learning would be helpful, most of them felt they had not well equipped with proper training and thus they ought to autonomously learn. This resulted in a doubtful of ability to carry out digital learning of English effectively.

In my opinion, the primary problems that most EFL teachers faced in regard to the use of technology in classroom is that we haven't accepted much professional training on how to integrate technology in our classroom. Even though we are using technology in our classroom, it is a result of personal adaptation and improvement. (P7. WR)

Lastly yet importantly, some participants pointed out that they need support from the authorities to deal with this technological learning in the era of industrial revolution 4.0. They required a continuous professional development such as seminar, training, workshop, or FGD. It truly assists them in designing classroom activities based on digital learning pedagogy. In addition, the participants added that enhancing the human resources should be along with the improvement of internet facility to ensure that teaching and learning using technology smoothly run as expectation.

Our university where we are teaching does not sufficiently equip EFL teachers with professional training on technology for language learning, such as seminar, workshop, or FGD. To achieve the goal of digital learning, we need these professional developments. One more thing that is crucial is the internet resource. (P1. Int)

\section{Discussion}

The present study reveals that the EFL teachers acknowledge a strong belief in the significance of digital technology in language learning. Unlike a conventional method of teaching, where teachers become a central of learning, the EFL teachers exhibited an awareness of designing an inductive, interesting, and interactive approach by means of technology to assist learners enhance language practices. However, these teachers also dealt with a wide 
range of personal and contextual challenges, which not only created a discrepancy between their beliefs and teaching practices, but further also influenced their lack of efficacy in digital learning.

First, in many Indonesian educational contexts, there is a frequent preference to concern more on grammar accuracy and face-to-face meeting rather than on integrating digital technology in language learning. Additionally, the Covid-19 pandemic which is never predicted in advanced forces teachers to design the most effective and efficient teaching and learning activities in social distancing measures. As a result, EFL teachers experience lack of adequate time and resources to conduct digital learning activities in the sudden policy to carry out online learning. This result confirms previous study on the gap between teachers' beliefs and classroom practices (e.g. Zheng $\&$ Borg, 2014). Further, many of the EFL teachers seemed unconfident in carrying their digital learning in the classroom. It is possibly caused by inadequate professional training experienced by the EFL teachers during preservice program. It is in line with the result reported by Nordin et al. (2013) that pre-service EFL teachers are slightly equipped with an effective guide to integrate ICT into classroom teaching practices. Likewise, this results is also consistent with Köse's (2016) finding that EFL teachers in Turkey did not recognize that they were highly competent to integrate digital technology learning into their classroom practices due to lack of professional training. Thus, EFL teachers require to receive tailored professional training about classroom technology integration in both pre- and in-services stages, where a variety of pedagogical input knowledge, tools, guidance, and materials are introduced, discussed, and demonstrated (Atmojo \& Nugroho, 2020; Cahyono et al., 2016).

Another major reason for the EFL teachers' lack of teaching efficacy is their proficiency to perform English skills like native English teachers in Indonesia influenced by their lack of confidence and ill-preparation of teaching. Although the teachers hold strong beliefs about the importance of digital technology for language learning, they seem reluctant to fully integrate it in their classroom. As depicted in the semi-structured interviews, lack of pre-teaching activities and limited internet source are the primary causes. As such, many of them thought digital learning of English will not be successful without adequate resources of facilities, including internet source and devices compatibility, and well-prepared learning designs. This result is as stated by Agarwal (2010) that EFL teachers and learners need to learn a lot to use digital devices properly, no matter how simple the devices and internet are. Often, when EFL teachers had already designed interesting technology-based activities, computer breakdown happened, and they may encountered technical problems (Heil et al., 2016, Nugroho \& Rahmawati, 2020). This obviously decreases the teachers' motivation and excitement to design digital learning activities.

Above all, although EFL teachers utilized digital technology in their teaching densely and with a strong belief of its advantages, the quality of the teaching varies and has to be enhanced through professional development training for technology-assisted language classroom. In this case, institutional 
Nugroho, A., \& Mutiaraningrum, I. (2020). EFL teachers' beliefs and practices about digital learning of English. EduLite: Journal of English Education, Literature, and Culture, 5 (2), 304-321. DOI: http://dx.doi.org/10.30659/e.5.2.304-321

policy and authorities play a crucial role to equip EFL teachers with sufficient knowledge and practices of digital learning, not only of providing trainings, workshops, and seminars, but also of supplying satisfactory internet source and digital facility (Wegerif, 2013). It is also noticed that EFL teachers tend to use digital devices, especially social networking sites, for gathering and communication rather than for the purpose of language learning with their students (Celik, 2013). That means the teachers' preferences over language teaching styles and their technical competence to use digital devices and platforms are crucial factors to ensure the success of technology-based language learning (Lam et al., 2018; Lee, 2019).

To address these challenges, it will also be more meaningful to introduce how to utilize and integrate digital technology in EFL classroom in order to assisting the teachers design technology-based learning activities. For the teachers who either require professional training or lack confidence in using technology for classroom learning, in-services workshops or trainings ought to be available. Notwithstanding the fact, plenty of literature about the integration of digital technology for language learning can be used by EFL teachers, who inevitably desire to make efforts in adapting these resources in their designs of classroom activities. Previous studies in this area clearly depict that digital devices offer EFL learners with various possibilities for enhancing their language skills, and obviously can be integrated in language classroom. For instance, the successful use of social networking sites in EFL classroom as reported by some scholars, i.e. WhatsApp (Ahmed, 2019); Facebook (Naghdipour, 2017; Slim \& Hafedh, 2019); Instagram (Aloraini, 2018; Listiani, 2016); Youtube (Alwehaibi, 2015); Email (Mohammad Alzu'bi \& Sabha, 2013; Usha Rani \& Nesara Kadanakuppe, 2014); and Google classroom (Al-Maroof \& Al-Emran, 2018; Heggart \& Yoo, 2018). These social networking sites are part of technological inventions that provide language learners with greater affordances for meaningful and authentic language use than are available in the classroom. In addition, these social media can be used as media to obtain fruitful insights for English teachers to enhance their Personal Learning Network by building networks with educators around the world, sharing experiences, and practicing language with speakers of other countries.

The current study has some implications for the realm of EFL teachers' professional development. First, the results indicate that a central target of pre-service teacher training and professional development programmes is to shift teachers' beliefs in their 'insufficiency' to integrate technology in language classroom. When EFL teachers are equipped with knowledge, ability, and technique, they will be more confident to perform teaching activities in technology-based language classroom. Second, the results can be used as reference for authorities. Most importantly, there is a need to involve policymakers in discussing and ensuring the efficacy of digital language learning. In particular, university leaders have to develop awareness that EFL teachers can perform outstanding technology-based teaching with adequate professional training and contextual support. With the support from authorities, EFL teachers and learners can engage in collaborative teaching to achieve the success of digital learning of English. Lastly, it is a worth saying 
that society has outreach a point that it is impossible to run away from the advancement of technology, thus it should be seen as a complement rather than an obstacle for second and foreign language learning (Finardi et al., 2016).

\section{CONCLUSION}

The in-hand study contributes to the literature on EFL teachers' beliefs and practices about digital learning of English. Several apparent discrepancies occur between the teachers' beliefs and classroom practices caused by lack of professional knowledge and personal challenges. It implies that a key issue with EFL digital learning is the teachers' lack of preparation and limited internet sources and facility. Although this study depicts a rich and in-depth delineation about Indonesian EFL teachers' beliefs and teaching practices, some limitations are acknowledge. First, the number of participants in this study slightly represents the abundant distribution of EFL teachers in Indonesia. Thus, future studies are suggested to involve greater number of participants from various universities and backgrounds. Second, some questions should be added in the written reflections to obtain more in-depth data about EFL teachers' beliefs and practices. Hence, future researches are strongly suggested to regularly examine the relation between teachers' beliefs and practices by integrating other questions, which have not been examined in this study, such as teachers' length of experience, the urgency of using technology, and how they improve their professional development. Apart from these challenges, future researchers, authorities, and professional development programmes should concern more on assisting EFL teachers fulfil the gap between their beliefs and classroom practices of English language teaching in digital era, and develop their sense of confidence and wellprepared in technology-based teaching.

\section{ACKNOWLEDGEMENTS}

Our deepest gratitude goes to all EFL teachers who have helpfully participated in the present research, and to all parties who valuably support the administration of this study (e.g. university authorities).

\section{REFERENCES}

Agarwal, M. K. (2010). Internet-based language learning and teaching. Innovative Infotechnologies for Science, Business and Education, 1(8), 3-7.

Ahmed, S. T. S. (2019). Chat and Learn: Effectiveness of Using WhatsApp as a Pedagogical Tool to Enhance EFL Learners Reading and Writing Skills. International Journal of English Language and Literature Studies, 8(2), 6168. https://doi.org/10.18488/journal.23.2019.82.61.68

Al-Maroof, R. A. S., \& Al-Emran, M. (2018). Students acceptance of Google classroom: An exploratory study using PLS-SEM approach. International Journal of Emerging Technologies in Learning (IJET), 13(06), 112-123. 
Nugroho, A., \& Mutiaraningrum, I. (2020). EFL teachers' beliefs and practices about digital learning of English. EduLite: Journal of English Education, Literature, and Culture, 5 (2), 304-321.

Al-Munawwarah, S. F. (2015). Teachers' perceptions on the Use of ICT in Indonesian EFL Learning Context. English Review: Journal of English Education, 3(1), 70-80.

Aloraini, N. (2018). Investigating Instagram as an EFL Learning Tool. Arab World English Journal, 4(4), 174-184. https://doi.org/10.24093/awej/call4.13

Alwehaibi, H. O. (2015). The Impact of Using YouTube in EFL Classroom on Enhancing EFL Students' Content Learning. Journal of College Teaching \& Learning (TLC), 12(2), 121-126. https://doi.org/10.19030/tlc.v12i2.9182

Atmojo, A. E. P. \& Nugroho, A. (2020). EFL Classes Must Go Online! Teaching Activities and Challenges during COVID-19 Pandemic in Indonesia. Register Journal, 13(1), 49-76, doi: 10.18326/rgt.v13i1.49-76.

Barkhuizen, G. (2014). Revisiting narrative frames: An instrument for investigating language teaching and learning. System, 47, 12-27.

Borg, S. (2015). Teacher cognition and language education: Research and practice. Bloomsbury Publishing.

Cahyono, B. Y., Kurnianti, O. D., \& Mutiaraningrum, I. (2016). Indonesian EFL Teachers' Application of TPACK in In-Service Education Teaching Practices Universitas Negeri Malang, Indonesia. International Journal of English Language Teaching, 4(5), 16-30.

Celik, S. (2013). Internet-assisted technologies for English language teaching in Turkish universities. Computer Assisted Language Learning, 26(5), 468-483.

Ertmer, P. A., \& Ottenbreit-Leftwich, A. T. (2010). Teacher technology change: How knowledge, confidence, beliefs, and culture intersect. Journal of Research on Technology in Education, 42(3), 255-284.

Ertmer, P. A., Ottenbreit-Leftwich, A. T., Sadik, O., Sendurur, E., \& Sendurur, P. (2012a). Teacher beliefs and technology integration practices: A critical relationship. Computers \& Education, 59(2), 423-435.

Ertmer, P. A., Ottenbreit-Leftwich, A. T., Sadik, O., Sendurur, E., \& Sendurur, P. (2012b). Teacher beliefs and technology integration practices: A critical relationship. Computers and Education, 59(2), 423-435. https://doi.org/10.1016/j.compedu.2012.02.001

Finardi, K. R., Leao, R. G., \& Amorim, G. B. (2016). Mobile assisted language learning: Affordances and limitations of Duolingo. Education and Linguistics Research, 2(2), 48-65.

Galvis, H. A. (2012). Understanding Beliefs, Teachers' Beliefs and Their Impact on the Use of Computer Technology. Profile Issues in Teachers' Professional Development, 14(2), 95-112.

Harding, J. (2018). Qualitative data analysis: From start to finish. SAGE Publications Limited.

Heggart, K. R., \& Yoo, J. (2018). Getting the most from google classroom: A 
pedagogical framework for tertiary educators. Australian Journal of Teacher Education, 43(3), 9.

Heil, C. R., Wu, J. S., Lee, J. J., \& Schmidt, T. (2016). A review of mobile language learning applications: Trends, challenges, and opportunities. The EuroCALL Review, 24(2), 32-50.

Hew, K. F., \& Brush, T. (2007). Integrating technology into K-12 teaching and learning: Current knowledge gaps and recommendations for future research. Educational Technology Research and Development, 55(3), 223252.

Hollweck, T. (2015). Robert K. Yin.(2014). Case Study Research Design and Methods . Thousand Oaks, CA: Sage. 282 pages. Canadian Journal of Program Evaluation, 30(1).

Inayati, D., \& Emaliana, I. (2017). The Relationship among Pre-Service EFL Teachers' Beliefs about Language Learning, Pedagogical Beliefs, and Beliefs about ICT Integration. Dinamika Imu, 17(1), 83-99.

Kim, C. M., Kim, M. K., Lee, C. J., Spector, J. M., \& DeMeester, K. (2013). Teacher beliefs and technology integration. Teaching and Teacher Education, 29(1), 76-85. https://doi.org/10.1016/j.tate.2012.08.005

Koehler, M. J., Mishra, P., \& Cain, W. (2013). What is technological pedagogical content knowledge (TPACK)? Journal of Education, 193(3), 13-19.

Köse, N. K. (2016). Technological Pedagogical Content Knowledge (tpack) of English Language Instructors. Journal of Educational \& Instructional Studies in the World, 6(2), 12-19.

Lailiyah, M., \& Cahyono, B. Y. (2017). Indonesian EFL Teachers' Self-Efficacy towards Technology Integration (SETI) and Their Use of Technology in EFL Teaching. Studies in English Language Teaching, 5(2), 344. https:// doi.org/10.22158/selt.v5n2p344

Lam, Y. (2000). Technophilia vs. technophobia: A preliminary look at why second-language teachers do or do not use technology in their classrooms. Canadian Modern Language Review, 56(3), 389-420.

Lam, Y. W., Hew, K. F., \& Chiu, K. F. (2018). Improving argumentative writing: Effects of a blended learning approach and gamification. Language Learning \& Technology, 22(1), 97-118.

Lan, W., \& Lam, R. (2020). Exploring an efl teacher's beliefs and practices in teaching topical debates in mainland China. Iranian Journal of Language Teaching Research, 8(1), 25-44.

Lee, J. S. (2019). Informal digital learning of English and second language vocabulary outcomes: Can quantity conquer quality? British Journal of Educational Technology, 50(2), 767-778.

Lee, J. S., \& Drajati, N. A. (2019). English as an international language beyond the ELT classroom. ELT Journal, 73(4), 419-427. https://doi.org/10.1093/elt/ccz018 
Nugroho, A., \& Mutiaraningrum, I. (2020). EFL teachers' beliefs and practices about digital learning of English. EduLite: Journal of English Education, Literature, and Culture, 5 (2), 304-321.

Lestariningsih, F.E., Madya, S. \& Nurkamto, J. (2020). Pedagogical problems encountered by teachers of English to Computer science students in the Indonesian context. Edulite: Journal of English Education, Literature, and Culture, 5(1), 1-13, doi: 10.30659/e.5.1.1-13

Listiani, G. (2016). The effectiveness of instagram writing compared to teacher centered writing to teach recount text to students with high and low motivation (The case of eight grade students in SMP Kesatrian 1 Semarang in the academic year of 2015/2016). ELT Forum: Journal of English Language Teaching, 5(1).

Liu, H., Lin, C. H., \& Zhang, D. (2017). Pedagogical beliefs and attitudes toward information and communication technology: a survey of teachers of English as a foreign language in China. Computer Assisted Language Learning, 30(8), 745-765.

Mohammad Alzu'bi, M. A., \& Sabha, M. R. N. (2013). Using mobile-based email for english foreign language learners. Turkish Online Journal of Educational Technology, 12(1), 178-186.

Mohsen, M. A., \& Shafeeq, C. P. (2014). EFL teachers' perceptions on blackboard applications. English Language Teaching, 7(11), 108-118. https://doi.org/10.5539/elt.v7n11p108

Naghdipour, B. (2017). 'Close your book and open your facebook': A case for extending classroom collaborative activities online. Journal of Asia TEFL, 14(1), 130-143. https://doi.org/10.18823/asiatefl.2017.14.1.9.130

Nordin, H., Davis, N., \& Ariffin, T. F. T. (2013). A Case Study of Secondary Preservice Teachers' Technological Pedagogical and Content Knowledge Mastery Level. Procedia - Social and Behavioral Sciences, 103, 1-9. https://doi.org/10.1016/j.sbspro.2013.10.300

Nugroho, A., Zamzami, M. R. A., \& Ukhrowiyah, N. F. (2020). Language input, learning environment, and motivation of a successful EFL learner. Journal on English as a Foreign Language ( JEFL ), 1O(1), 46-69.

Nugroho, A. \& Rahmawati, A. (2020). "Let's write a caption!": Utilizing Instagram to enhance ESP students' writing skills. Jurnal Basis, 7(1), 112, doi:10.33884/basisupb.v7i1.1782.

Onwuegbuzie, A. J., Leech, N. L., \& Collins, K. M. T. (2010). Innovative data collection strategies in qualitative research. Qualitative Report, 15(3), 696-726.

Ottenbreit-Leftwich, A., Liao, J. Y.-C., Sadik, O., \& Ertmer, P. (2018). Evolution of teachers' technology integration knowledge, beliefs, and practices: How can we support beginning teachers use of technology? Journal of Research on Technology in Education, 50(4), 282-304.

Rahamat, R. (2019). Designing mobile learning: Empirical journey to reality in Malaysian secondary school context. Edulite: Journal of English Education, Literature, and Culture, 4(1), 13-24, doi: 10.30659/e.4.1.1324.

Slim, H., \& Hafedh, M. (2019). Social media impact on language learning for 
specific purposes: A study in English for business administration. Teaching English with Technology, 19(1), 56-71.

Sundqvist, P., \& Sylvén, L. K. (2016). Extramural English in teaching and learning. Springer.

Tondeur, J., Pareja Roblin, N., van Braak, J., Voogt, J., \& Prestridge, S. (2017). Preparing beginning teachers for technology integration in education: Ready for take-off? Technology, Pedagogy and Education, 26(2), 157-177.

Usha Rani, N., \& Nesara Kadanakuppe. (2014). Communication Technology and Development? A Study of E-learning Intervention in Engineering Education in Karnataka, India. Journal of Media and Social Development, 2(3), 52-72. http://www.uni-mysore.ac.in/journal-media-and-socialdevelopment

Voogt, J., \& McKenney, S. (2017). TPACK in teacher education: Are we preparing teachers to use technology for early literacy? Technology, Pedagogy and Education, 26(1), 69-83.

Voogt, J., Tilya, F., \& van den Akker, J. (2009). Science teacher learning of MBL-supported student-centered science education in the context of secondary education in Tanzania. Journal of Science Education and Technology, 18(5), 429-438.

Wegerif, R. (2013). Dialogic: Education for the internet age. Routledge.

Wilkins, J. L. M. (2008). The relationship among elementary teachers' content knowledge, attitudes, beliefs, and practices. Journal of Mathematics Teacher Education, 11(2), 139-164.

Yang, S. C., \& Huang, Y.-F. (2008). A study of high school English teachers' behavior, concerns and beliefs in integrating information technology into English instruction. Computers in Human Behavior, 24(3), 1085-1103.

Yin, R. K. (2015). Qualitative research from start to finish. Guilford publications.

Yuan, R., \& Lee, I. (2014). Pre-service teachers' changing beliefs in the teaching practicum: Three cases in an EFL context. System, 44, 1-12.

Zheng, X., \& Borg, S. (2014). Task-based learning and teaching in China: Secondary school teachers' beliefs and practices. Language Teaching Research, 18(2), 205-221. 
Nugroho, A., \& Mutiaraningrum, I. (2020). EFL teachers' beliefs and practices about digital learning of English. EduLite: Journal of English Education, Literature, and Culture, 5 (2), 304-321.

\section{Questions on Written Reflections}

\section{APPENDIX}

- In your beliefs, what is the importance of digital technology in English language classroom?

- How do you integrate digital technology in English language classroom?

- How confident are in using digital technology for language teaching? What are the challenges you face in teaching English using digital technology?

- What support (e.g. school curriculum, professional development, and authorities) do you need to improve the efficacy of your technologybased teaching? 